\title{
Epigenetic field for cancerization: its cause and clinical implications
}

\author{
Toshikazu Ushijima \\ From São Paulo Advanced School of Comparative Oncology \\ Águas de São Pedro, Brazil. 30 September - 6 October 2012
}

Epigenetic alterations are present not only in cancer cells but also in non-cancerous tissues. Accumulation levels of aberrant DNA methylation in non-cancerous tissues can correlate with risk of cancer development, especially in chronic inflammation-associated cancers [1-3]. The close correlation in non-cancerous tissues was prominent for epigenetic alterations, compared with genetic alterations, and formed a concept of "epigenetic field for cancerization (epigenetic field defect)". In gastric cancers, close correlation between methylation levels and cancer risk has been demonstrated [4].

As mechanisms for methylation induction in the stomach, infection by Helicobacter pylori (H. pylori), the major cause of gastric cancers, was implicated in humans [5], and was demonstrated in Mongolian gerbils [6]. Especially, a critical role of inflammation triggered by $H$. pylori infection, not by high concentrations of ethanol or salt, was demonstrated, suggesting the importance of specific chronic inflammation [7]. Gene expression analysis showed that expression levels of $I l 1 b$, Nos, and $\operatorname{Tnf}$ were well correlated with methylation levels induced.

To dissect molecular mechanisms for induction of epigenetic alterations, a mouse colitis model induced by dextran sulfate sodium (DSS) was used. First, we isolated genes methylated in colon tumors induced by DSS and azoxymethane, and showed that these genes were methylated in non-cancerous colonic mucosae, forming an epigenetic field. Aberrant methylation was induced even in SCID mice, which lack functional T- and B-lymphocytes, and it was shown that lymphocytes are not essential in methylation induction [8]. By chromatinimmunoprecipitation-on-Chip analysis of H3K27me3, aberrant H3K27me3 was shown to be induced by colitis,

Correspondence: tushijim@ncc.go.jp

Division of Epigenomics, National Cancer Center Research Institute, Japan and can be carried into cancer tissues and function as a premark for induction of aberrant DNA methylation [9].

One of the major translations of the epigenetic field for cancerization is its use as a cancer risk marker. By searching for $\mathrm{CpG}$ islands differentially methylated in gastric mucosae of gastric cancer patients and healthy volunteers, both of which had past infection by H. pylori, we were able to isolate and validate seven differentially methylated $\mathrm{CpG}$ islands. The new markers had large areas under the receiver-operating characteristic curves (0.78-0.84) and high odds ratios (12.7-36.0) even among individuals with past $H$. pylori infection, compared with two currently available markers $(0.60-0.65,5.0-$ 5.7) [10]. We are currently conducting a prospective study to predict patients who suffer from metachronous gastric cancers among gastric cancer patients treated by endoscopic submucosal dissection.

Another translation is prevention of cancers. Several studies involving viral oncogenes and chemical carcinogens showed that epigenetic cancer prevention is possible, but there have been no studies for the usefulness of epigenetic cancer prevention in chronic inflammation-associated cancers. We administered 5-aza-2'-deoxycitidine (5-aza-dC) to Mongolian gerbils infected with $H$. pylori after administration of $N$-methyl- $N$-nitrosourea. It was shown that the incidence of gastric cancers was suppressed almost to half of that in gerbils without 5-aza-dC [Niwa, submitted].

These findings vividly show that the epigenetic field defect has its unique characteristics, such as ease of measurement and reversibility, and harbors a rich chance of clinical translations.

\section{Competing interests}

There are no competing interests in this presentation.

Published: 4 April 2013

(c) 2013 Ushijima; licensee BioMed Central Ltd. This is an Open Access article distributed under the terms of the Creative Commons Attribution License (http://creativecommons.org/licenses/by/2.0), which permits unrestricted use, distribution, and reproduction in any medium, provided the original work is properly cited. 


\section{References}

1. Ushijima T, Hattori N: Molecular Pathways: Involvement of Helicobacter pylori-Triggered Inflammation in the Formation of an Epigenetic Field Defect, and Its Usefulness as Cancer Risk and Exposure Markers. Clin Cancer Res 2012, 18:923-929.

2. Chiba T, Marusawa H, Ushijima T: Inflammation-associated cancer development in digestive organs: mechanisms and roles for genetic and epigenetic modulation. Gastroenterology 2012, 143:550-563.

3. Ushijima T: Epigenetic field for cancerization. J Biochem Mol Biol 2007, 40:142-150.

4. Nakajima T, Maekita T, Oda I, Gotoda T, Yamamoto S, Umemura S, Ichinose M, Sugimura T, Ushijima T, Saito D: Higher methylation levels in gastric mucosae significantly correlate with higher risk of gastric cancers. Cancer Epidemiol Biomarkers Prev 2006, 15:2317-2321.

5. Maekita T, Nakazawa K, Mihara M, Nakajima T, Yanaoka K, Iguchi M, Arii K, Kaneda A, Tsukamoto T, Tatematsu M, Tamura G, Saito D, Sugimura T, Ichinose M, Ushijima T: High levels of aberrant DNA methylation in Helicobacter pylori-infected gastric mucosae and its possible association with gastric cancer risk. Clin Cancer Res 2006, 12:989-995.

6. Niwa T, Tsukamoto T, Toyoda T, Mori A, Tanaka H, Maekita T, Ichinose M, Tatematsu M, Ushijima T: Inflammatory processes triggered by Helicobacter pylori infection cause aberrant DNA methylation in gastric epithelial cells. Cancer Res 2010, 70:1430-1440.

7. Hur K, Niwa T, Toyoda T, Tsukamoto T, Tatematsu M, Yang HK, Ushijima T: Insufficient role of cell proliferation in aberrant DNA methylation induction and involvement of specific types of inflammation. Carcinogenesis 2011, 32:35-41.

8. Katsurano M, Niwa T, Yasui Y, Shigematsu Y, Yamashita S, Takeshima $H$, Lee MS, Kim YJ, Tanaka T, Ushijima T: Early-stage formation of an epigenetic field defect in a mouse colitis model, and non-essential roles of T- and B-cells in DNA methylation induction. Oncogene 2012, 31:342-351.

9. Takeshima H, Ikegami D, Wakabayashi M, Niwa T, Kim YJ, Ushijima T: Induction of aberrant trimethylation of histone $\mathrm{H} 3$ lysine 27 by inflammation in mouse colonic epithelial cells. Carcinogenesis 2012, 33(12):2384-90.

10. Nanjo S, Asada K, Yamashita S, Nakajima T, Nakazawa K, Maekita T, Ichinose M, Sugiyama T, Ushijima T: Identification of gastric cancer risk markers that are informative in individuals with past $\mathrm{H}$. pylori infection. Gastric Cancer 2012, 15(4):382-8.

doi:10.1186/1753-6561-7-S2-K22

Cite this article as: Ushijima: Epigenetic field for cancerization: its cause and clinical implications. BMC Proceedings 2013 7(Suppl 2):K22.

\section{Submit your next manuscript to BioMed Central and take full advantage of:}

- Convenient online submission

- Thorough peer review

- No space constraints or color figure charges

- Immediate publication on acceptance

- Inclusion in PubMed, CAS, Scopus and Google Scholar

- Research which is freely available for redistribution

Submit your manuscript at www.biomedcentral.com/submit
C Biomed Central 